\title{
VRIJHEID, BURGERLIJK ACTIVISME EN KRITIEK OP HET ABSOLUTISME: \\ ENKELE CASUSSEN VAN HET NEDERLANDSE REPUBLICANISME IN DE VERLICHTING
}

\begin{abstract}
A b stract. De bedoeling van deze bijdrage is te laten zien hoe de ontwikkeling van de republikeinse gedachten in Nederland in de laatste decennia van de achttiende eeuw verliep. Daarvoor presenteer ik drie casussen van het Nederlands republicanisme die volgens mij het meest cruciaal waren voor de vorming van de Nederlandse identiteit in de vroegmoderne tijd. Bij de analyse van de casussen probeer ik weer te geven hoe de republikeinse boodschap tot stand kwam: ik kijk zowel naar de ideologie die in de republikeinse concepten opgesloten lag, als naar de retorische weergave van de republikeinse ideeën - hoe ze, in de vorm van teksten en prenten, aan de lezer werden gepresenteerd.
\end{abstract}

Trefwoorden: republicanisme; vrijheid; verlichting; Willem V; klassieke oudheid; Bataafse mythe; politieke satire; kritiek; patriotten.

\section{CASUS 1:}

\section{REPUBLICANISME GEMYTHOLOGISEERD OF DE OORSPRONG VAN DE REPUBLIKEINSE GEDACHTEN IN NEDERLAND}

De periode die ik voor mijn onderzoek koos - de roerige, laatste decennia van de achttiende eeuw - leent zich het best om voorbeelden te vinden voor het bloeien van de republikeinse gedachten in Nederland. Juist toen vond daar een heftige strijd plaats die de geschiedenis is ingegaan als de patriot-

Dr. JAN URBANIAK is Adiunkt (Universitair Hoofddocent) bij de Katedra Filologii Niderlandzkiej (Afdeling Nederlandse Filologie) van de Uniwersytet Wrocławski (Universiteit van Wrocław). Zijn onderzoeksterrein is de Nederlandstalige literatuur en cultuur van de Verlichting, met name in verband met de patriotten. Corespondentie-adres: Katedra Filologii Niderlandzkiej, Uniwersytet Wrocławski, ul. Kuźnicza 21-22, 50-138 Wrocław, Polen; e-mail: jan.urbaniak@uwr.edu.pl. ORCID: https://orcid.org/0000-0002-3332-3645. 
tenrevolutie (1781-1787) ${ }^{1}$ - een strijd tussen aanhangers van het Oranjehuis (belichaamd door stadhouder Willem $\mathrm{V}$ en zijn entourage) en de kritische burgers bij wie de republikeinse gedachten hoog in het vaandel stonden. Het kwam toen tot botsing tussen representanten van twee visies van de staat: het semi-absolutistische hof van Willem V (1748-1806) en de monarchale claims van de prins werden blootgesteld aan hevige kritiek op de gevaren van het ouderwetse monarchisme dat volgens velen niet paste bij de oeroude, "natuurlijke" Nederlandse vrijheidszin. Dat debat over de toekomst van Nederland vormt in mijn bijdrage een niet onbelangrijke achtergrond.

Het debat stelt de dichotomie van de Nederlandse staat bloot. Op het eerste gezicht leek de Nederlandse Republiek in de laatste decennia van de achttiende eeuw een nogal complexe politieke structuur te hebben. In zijn klassiek geworden boek (Patriots republikanisme. Politieke cultuur in $\mathrm{Ne}$ derland 1766-1787, Amsterdam University Press, 1995) noemde de Nederlandse historicus Stephan Klein Nederland "een monarchie in republikeinse vermomming" (Klein 147).

Deze dichotomie van de Nederlandse politieke structuur, gretig beklemtoond door de patriottische politieke denkers ${ }^{2}$ - vurige tegenstanders van elke vorm van het monarchisme - was met name op het militair-politieke vlak te zien. De stadhouder eigende zich de meest cruciale functies in het land toe (hij was zowel kapitein-generaal als admiraal-generaal) en zijn entourage was sterk aanwezig, zowel bij het benoemen van belangrijke politieke ambten als bij niet minder prestigieuze privé-bedieningen op het hof. ${ }^{3}$ De principes van gunst, eer en volgzaamheid van de orangistische hovelingen jegens hun stadhouder voerden de boventoon en de macht werd tot een kleine aanhang van Willem $\mathrm{V}$ beperkt. In de ogen van de tegenstanders van de Oranjes maakte dat van de hofhouding van Willem $V$ een gecorrumpeerde kliek van gunstelingen, voor wie loyaliteit aan hun opperbevelhebber boven trouw aan het vaderland prevaleerde. ${ }^{4}$

\footnotetext{
${ }^{1}$ Over de patriottenrevolutie en de rol van Willem V bij deze gebeurtenis zie o.a.: Wildschut; Rosendaal; Meerkerk.

${ }^{2}$ Als voorbeeld van het anti-monarchale offensief van de patriotten zie bijv. Van Nassau la Leck, 1780; Van Irhoven van Dam, 1782; Johannes Allart, 1783, maar ook gretig gelezen politieke bladen zoals De Post van den Neder-Rhyn (1781-1787), De Politieke Kruyer (17821787) of Le Politique Hollandais (1781-1784).

${ }^{3}$ Een goed voorbeeld van de combinatie van politieke ambten en privé-bedieningen op het orangistische hof was Willem van Lynden van Hemmen (1729-1787), die naast de functie van afgevaardigde van de Staten-Generaal namens de Staten van Gelderland ook de functie van gouverneur van de kinderen van Willem $\mathrm{V}$ vervulde.

${ }^{4}$ Voor dergelijke kritiek zie bijv. De Politieke Kruyer, II, 73, 996.
} 
De republikeinse tegenstanders van Willem V en zijn hof beriepen zich op de oude traditie van het republicanisme. In hun kritiek op de stadhouder maakten ze gretig gebruik van klassieke voorbeelden. In dergelijke kritiek werd de stadhouder als antiheld gepresenteerd, terwijl men de standvastigheid van Cato (95-46 v.Ch.) in zijn strijd tegen Julius Caesar (100-44 v.Ch.) bejubelde en meermaals Cicero's (106-43 v.Ch.) term constitutio als voorbeeld aanhaalde. Deze term (die gelijk was aan de Aristotelische politeia) beoogde een ideale samenwerking tussen politiek geëngageerde vrije burgers en het machtsapparaat (Madox 51). Een voorbeeld bij uitstek vonden de $\mathrm{Ne}$ derlandse republikeinen echter vooral terug in de eigen vaderlandse geschiedenis. Het gaat om Claudius Civilis (25-?), de legendarische leider van de opstand van de Bataven tegen de Romeinen (ca. 69-70) die sinds de vroege zestiende eeuw in herinnering werd geroepen in het kader van de zogenaamde "Bataafse mythe" (Haitsma Mulier). Hij belichaamde op z'n best de Nederlandse vrijheidszin en werd in de achttiende eeuw, toen de discussie over de staatstructuur weer oplaaide, een icoon van het republikeins denken. Zijn nog in de zestiende eeuw gebruikte bijnamen, zoals de Batavorum Imperator en de vindex libertatis (beschermer der vrijheid) ${ }^{5}$ verloren tweehonderd jaar later niets aan hun betekenis - ook toen werd hij nog steeds gezien als de Nederlandse tegenhanger van de evenzo strijdlustige en standvastige Cato (van Gelderen 40).

Het verhaal rond Claudius Civilis werd in de achttiende eeuw een van de elementen van het revolutionaire programma op het Nederlandse toneel. Zijn strijd tegen de Romeinen werd aan de recente twisten tussen de patriotten en orangisten gekoppeld, waarbij de partijen in de strijd al te duidelijk werden afgetekend. In het Bataafs drama Claudius Civilis (1779) van Willem Haverkorn de Jonge (1753-1826) werd het sterk gemythologiseerde verleden vanuit republikeins perspectief gepresenteerd (Leemans \& Johannes 702). Haverkorn maakte van Civilis de "grondlegger der Bataafsche Vrijheid" (zoals de ondertitel van het werk luidde) - een onwankelbare held met mythische trekken. In het "Voorwoord" kunnen we het imago van Civilis reconstrueren (Haverkorn z.p.):

Civilis (...) wederstond de Romeinen door standvastigheid en heldendeugd, geene wederwaardigheden hoe groot, verwyderden hem van zynen pligt; in den stryd, byna zyn gezicht verlooren hebbende, behield hy zynen moed (...),

\footnotetext{
${ }^{5}$ De bijnamen komen voort uit de dichtbundel Nova poemata van Janus Dousa uit 1575, waarin de dichter het verzet van de inwoners van Leiden tegen de Spaanse troepen tijdens de tachtigjarige oorlog met de vrijheidsstrijd der Bataven onder Claudius Civilis vergelijkt.
} 
was hy de grootste Veldheer die zyn Volk van de Romeinsche heerschappy vrystreed, en door de Vryheid, met onverwelkbre laauwrieren, zyn heldendeugd ten loon, gekroond wierd.

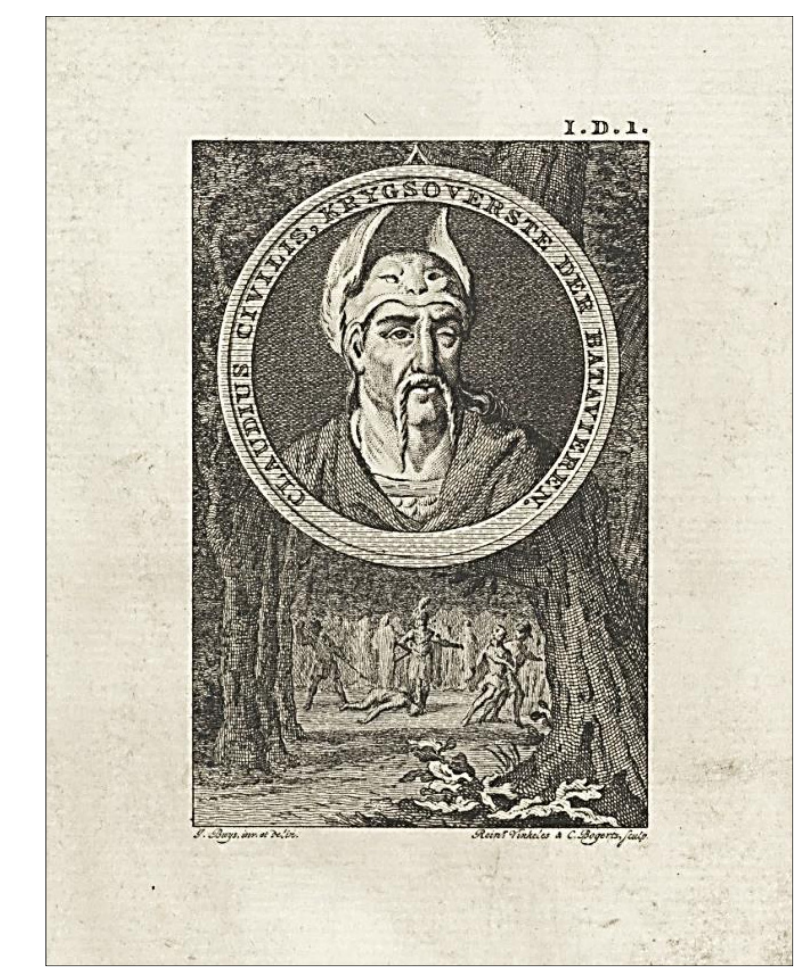

Afbeelding 1. Portret van Claudius Civilis, leider van de opstand van de Batavieren tegen de Romeinen, Reinier Vinkeles (I), Cornelis Bogerts (naar tekening van Jacobus Buys), 1783-1795. Rijksmuseum, Amsterdam

Civilis werd dus metaforisch bekroond en bejubeld en zodoende verankerd in het Nederlandse, republikeinse bewustzijn. Ook de schrijver Simon Stij1 (1731-1804) zag in Claudius Civilis de grondlegger van de Nederlandse, republikeinse vrijheidszin (Stijl). Voor hem was hij iemand die de typisch Nederlandse republikeinse vrijheidsgenen ("een eigene trek") in een door natuurlijk recht gesanctioneerde strijd kanaliseerde (Stij1 436, 449, 455). Op dat recht beriep men zich altijd als vreemde heersers zich aan Hollandse (Nederlandse) vrijheid leken te vergrijpen (van Sas 49-50).

Het verlichte optimisme van Stijl, dat hij op het republikeins bestel en het klassieke verleden projecteerde, werd genuanceerd door een verhandeling die, 
samen met de eerste editie van Stijls magistrale werk Opkomst en bloei der verenigde Nederlanden, in éénzelfde bundel werd uitgegeven. Het gaat om een tekst van de Engelsman Edward Wortley Montagu (1678-1761) getiteld Reflections on the rise and fall of the antieur republicks. Adapted to the present state of Great Britain (A. Millar, 1760). ${ }^{6}$ In plaats van lof over klassiek republicanisme (met uitzondering van Carthago) en het versieren van hoofden van Cato of Cicero met lauwerkransen, treffen we in deze verhandeling eerder voorbeelden van droevige lotgevallen van oude republieken en kwaadaardige gevolgen van misbruik van de publieke moraal (Montagu 13). Montagu liet zien dat het republicanisme geen kant-en-klaar concept was dat onvoorwaardelijk geluk, weelde en vrijheid garandeerde. Deze waarschuwing werd ook door Nederlandse schrijvers vaak herhaald.

De publicist Cornelis Zillesen (1736-1828) zag zodoende in de klassieke voorbeelden van republikeins gedachtengoed vooral een samenstelling van politieke fouten en tekortkomingen (Zillesen, Welmeenende 35-39). Corruptie en losbandigheid van de burgers (hier leverde Zillesen een voorbeeld van het eforaat in het klassieke Sparta) ${ }^{7}$ droegen bij tot de val van de staat. Het in handen geven van de macht aan de burgers (het eforaat was een goed voorbeeld daarvan) kon zodoende negatieve (zelfs gevaarlijke) gevolgen voor de staat met zich meebrengen. ${ }^{8}$ Het voorbeeld van het antieke Sparta was voor Zillesen een spiegelbeeld voor de achttiende-eeuwse Republiek. Om de fouten van de negatieve werking van het eforaat te voorkomen, benadrukte de auteur de waarde van de morele heroriëntatie van het Nederlandse volk: de deugd moest altijd voor democratische hervormingen van de burgers komen, zo leek het motto van Zillesens overpeinzingen (Onderzoek, I, 140).

Ook nog voor Zillesen en Montagu (en lang voor de patriottenrevolutie) waren er stemmen die uitwezen dat men zich in Nederland niet blind staarde op klassieke voorbeelden. Ferdinand Lieven de Beaufort (1675-1730) zag in zijn traktaat Verhandeling van de vryheit in den burgerstaet (1737) veel gelijkenissen qua staatstructuur tussen Rome en de Republiek, maar bestempelde Rome geenszins als voorbeeld. In zijn optiek waren de Romeinen behept met machtslust en genotzucht wat negatieve gevolgen moest hebben. Hij illustreerde dat met het voorbeeld van de eerste Romeinse keizer Augu-

\footnotetext{
${ }^{6}$ In mijn bijdrage maak ik gebruik van de tweede druk van de verhandeling (Londen 1760).

${ }^{7}$ Het gaat om de hoge ambtenaren van de Spartaanse staat die de naleving van de Spartaanse levenswijze controleerden.

${ }^{8}$ Voor de bedenkingen van Zillesen over de Spartaanse eforen zie ook zijn Onderzoek der oorzaaken van de opkomst, het verval en herstel, der voornaamste oude en hedendaagsche volken (Utrecht 1781-1784).
} 
stus (63-14 v.Ch.) die steeds meer verschillende bevoegdheden van republikeinse magistraten naar zich toetrok, waardoor hij als alleenheerser de feitelijke macht over Rome in handen kreeg (Meijer 2001, 25-33). De Beaufort liet daarmee niet alleen zien dat de tirannieke macht het republikeinse bestel in de weg stond (dat was uiterst vanzelfsprekend), maar ook dat iedereen die met de macht (in welke vorm dan ook) te maken krijgt, gemakkelijk bedorven kan worden. Dat gold zowel voor alleenheersers, als bijvoorbeeld voor volksvergaderingen. Zedenverval was het grootste gevaar voor de macht, aldus de auteur (Velema 2010, 12-13).

CASUS 2:

\section{REPUBLICANISME GEACTIVEERD OF DE ACTIEVE ROL VAN DE BURGER IN HET STAATSBESTEL}

Het klassieke ideaal van de virtus - de participatie van de burgers in het staatsbestel - werd door de aanhangers van het republicanisme sterk aangeprezen, ongeacht de risico's die de macht met zich meebracht. Een actieve burger, die wijs, trouw, dapper, deugdzaam en vrijheidslievend was, stond garant voor het natuurlijke evenwicht in de staat. Daarbij speelde de sociale verantwoordelijkheid voor zichzelf, maar vooral voor de hele gemeenschap een rol. Ook het idee van de burgerbewapening, dat elke bewapende burger veiligstelde voor de willekeur van het reguliere leger, was hier van essentieel belang. Verder moest de burger ook invloed hebben op de samenstelling van de regering.

Een schilderij van Romeyn de Hooghe (1645-1708) laat de burgerlijke participatie in het staatsbestel zien. Het schilderij versiert het stadhuis van Enkhuizen (gebouwd tussen 1686 en 1688), waarvan het interieur de innige band tussen de bestuurders van Enkhuizen en het politieke erfgoed van de Romeinse republiek moest tonen. Op het schilderij zien we het kiezen van de burgemeesters in het antieke Rome. Ze worden door loting gekozen, waarbij iedere stem telt. Om de rechtvaardigheid van het kiesproces te benadrukken zien we op de voorgrond van het schilderij het zwaard van justitie (Bedaux, Groot en Hagen 153). Het beeld van De Hooghe is slechts een element van het artistieke decor van het stadhuis met voorstellingen die naar de Romeinse republikeinse oudheid verwijzen. De bedoeling was zonneklaar: de burgemeesters van Enkhuizen moesten aan de consuls van Rome doen denken. Hier wemelt het van verschillende allegorische figuren, zoals waardig- 
heid, vrijheid of het wijze staatsbestuur. Boven de artistieke decoratie pronkt een veelzeggend citaat uit Cicero's Catilinarische redevoering: "Sij draagt sorg dat het gemeen best geen schaderen lijd" (Van Eikema Hommes en Bakker 232). De bestuurspraktijk die gestoeld was op een goede samenwerking tussen burgers en regenten, maar ook op de zorg van de regeerders voor de onderdanen, werd dus in het besproken geval met de klassieke republieken geïdentificeerd.

Ook in verschillende geschriften uit die tijd kan men een dergelijke identificatie vinden. Een goed voorbeeld daarvan is het anoniem uitgegeven pamflet Aan het volk van Nederland van Joan Derk van der Capellen (17411784) uit 1781. Het is niet toevallig dat het pamflet het licht zag precies twee eeuwen en twee maanden nadat de Staten-Generaal te Den Haag, in een plakkaat van 26 juli 1581 (bekend onder de naam Verlatinge), de bevolking van de Nederlandse gewesten hadden verboden de Spaanse koning Filips II nog langer te gehoorzamen (Kossmann 249). In Aan het volk van Nederland formuleerde de auteur de klassieke gedachte dat alleen een volk dat zichzelf wist te verdedigen ook werkelijk vrij kon zijn (Van Sas 199). Vandaar het idee van de burgerbewapening, voortgekomen uit het antieke Sparta. De context van Aan het volk van Nederland was heel breed. Van der Capellen beriep zich ook op de voorbeelden uit de Bijbel en natuurrecht, waardoor zijn idee van de nationale burgerbewapening niet alleen maar patriottisch, maar ook verlicht-christelijk geïnterpreteerd kon worden. Vandaar de toespeling van Van der Capellen op het Boek Samuel uit het Oude Testament en het daar geformuleerde ideaalbeeld van de heerser (vertegenwoordigd door Samuel) dat indirect aan het imago van Willem V tegengesteld werd. In een van de passages van zijn pamflet vraagt Van der Capellen zich af (106-107):

Kan zo'n Prins, die openlijk uitspreekt, dat hij het zich een onwaardeerbaar voorrecht rekent het voorwerp der liefde van een vrij volk te wezen, en niettemin een gezag aanvaardt en erfelijk aan zijn geslacht verbindt, dat met alle denkbeelden over vrijheid strijdt, kan zo'n prins in ernst eisen dat men hem gelooft?

Dat vermeende "strijden over vrijheid" is voor Van der Capellen een simpel bedrog dat getuigt van de onbetrouwbaarheid van de Oranjes en hun entourage - een middel om het volk in de maling te nemen en zodoende meer macht te vergaren. De auteur formuleert een waarschuwing: "Geloof me! het bedriegen en veinzen is de vorsten evenzo eigen als het onophoudelijk streven naar meer en hoger macht" (Van der Capellen 107). 


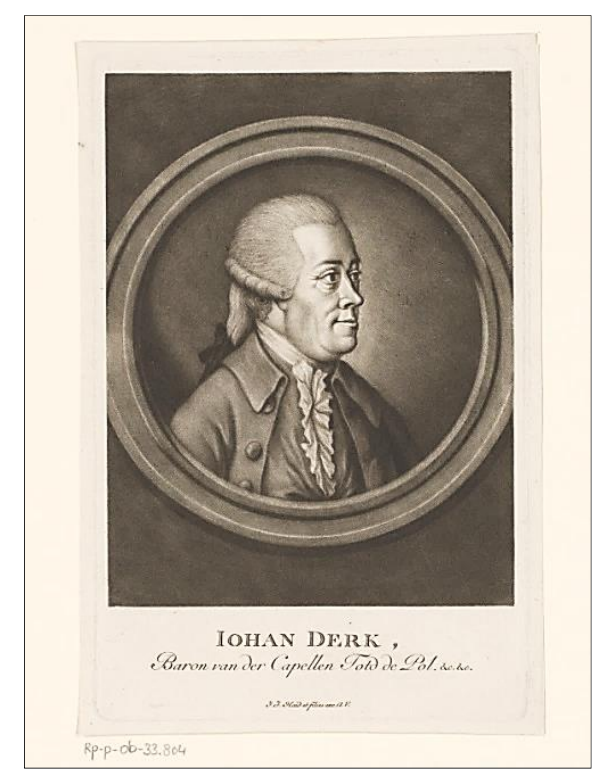

Afbeelding 2. Portret van Joan Derk van der Capellen, Johann Jacob Haid (?), 1751-1767. Rijksmuseum, Amsterdam

Om deze vorstelijke macht te beperken laat Van der Capellen het Nederlandse volk zich wapenen - het klassieke idee dat nog voor Nederland in het naburige Engeland werd geïntroduceerd. Dat idee bestempelde daar de sociaaleconomische ontwikkeling van de Engelse burgers, die de kans wilden grijpen om niet alleen maar hun onafhankelijkheidspositie te handhaven, maar ook hun kapitaal veilig te stellen (Robertson 32-38; Klein 176-179). Het startsein voor de burgerbewapening van de Engelse welgestelde burgers werd gegeven door de Schotse patriot Andrew Fletcher (1655-1716). In het pamflet Discours of government with relation to militias uit 1698 zette hij deze kwestie uiteen. Het pamflet werd door Van der Capellen naar het Nederlands vertaald, wat laat vermoeden dat de auteur van Aan het volk van Nederland juist bij Fletcher zijn inspiratie zocht (Zwitszer 12-13; Evers 210). ${ }^{9}$

Naast de gedachten van Van der Capellen, die het klassieke, republikeinse stempel droegen, was ook zijn imago niet vrij van de republikeinse identificatie met het klassieke verleden. In het patriottische blad De Politieke

\footnotetext{
${ }^{9}$ In zijn politieke publicistiek maakte Van der Capellen ook gretig gebruik van het oeuvre van andere Engelse denkers: John Locke (Two Treatises of Government, 1690), David Hume (History of England, 1754-1762), Francis Hutcheson (A System of Moral Philosophy in Three Books, 1755), Richard Price (Observations, 1776 en Additional observations, 1777) of Joseph Priestley (Essay, 1783). Zie daarvoor: Wessels 121-137; Zwitser 7-16; Evers 206-217.
} 
Kruyer (1782-1787) werd zijn "mannelyke styl" met de "nadrukkelyke welsprekendheid" van de Romeinse stoïcijnse senator Brutus, de stichter van de Romeinse Republiek (545-509 v.Ch.) vergeleken, "den laatsten der Romeinen, aan wien hy [Van der Capellen - JU] in onverzettelykheid en opregtheid van zyn karakter gelyk was" (Politieke Kruyer III, 2167).

Ook de sculptuur van deze grote held van de patriotten doet denken aan het Romeinse, klassieke erfgoed en verraadt de identificatie van de patriottische voormannen met het republicanisme. Als we naar het beeldhouwwerk kijken dat Van der Capellen voorstelt (dit werd ontworpen door de Italiaanse neoclassicistische beeldhouwer Giuseppe Ceracchi in 1780), zien we hem in de gedaante van een Romeinse volkstribuun, tribunus plebis - wat de strekking van het werk benadrukt. Voor zijn tijdgenoten was Van der Capellen vooral de vertegenwoordiger van het Nederlandse volk (ongeacht zijn aristocratische afkomst), de verdediger van de onderdanen tegen de semi-absolutistische macht van de orangistische hofkringen van Willem V (Velema 14).

\section{CASUS 3:}

\section{REPUBLICANISME IN ACTIE OF WILLEM V VERSMAAD}

Het burgerlijk activisme van de patriottische aanhang kwam ook tot uiting in een stroom kritische pamfletten en spotprenten tegen de macht van Willem V cum suis. ${ }^{10}$ In de periode 1780-1787 verschenen er ruim tweehonderd van dergelijke prenten in Nederland (van der Berg 7). De doelstelling van dergelijke kritiek was overduidelijk - het ging om het versmaden van de orangistische politieke elites en het aan de kaak stellen van hun monarchale claims. Hoewel een stadhouder in het Nederlandse staatsbestel geen koning was, begon zijn status in de loop van de achttiende eeuw wel een koninklijk tintje te krijgen (Leemans \& Johannes 657). Door het creëren van het negatieve imago van het Oranjehof ("eene secte in Nederland"), ${ }^{11}$ hoopten de patriotten hun tegenstanders van het politieke toneel te weren, of tenminste in het defensief te dringen. Het mikpunt van hun propaganda was met name Willem V, de vorst die de republikeinse zeden van de Nederlandse natie leek te hebben ondermijnd en geperverteerd (Velema 29).

\footnotetext{
${ }^{10}$ Deze kritiek is natuurlijkerwijs slechts één kant van het actieve beeldvormingsprogramma rond de Oranjes. Naast de kritische uitlatingen vanuit de patriottische gelederen hebben we ook voorbeelden van lof- en vreugdeliederen gewijd aan Willem V. Deze zijn vooral te vinden voor 1780. Zie daarvoor: Mörke; Leemans \& Johannes 662-663.

${ }^{11}$ De Politieke Kruyer, dl. V, nr 216.
} 


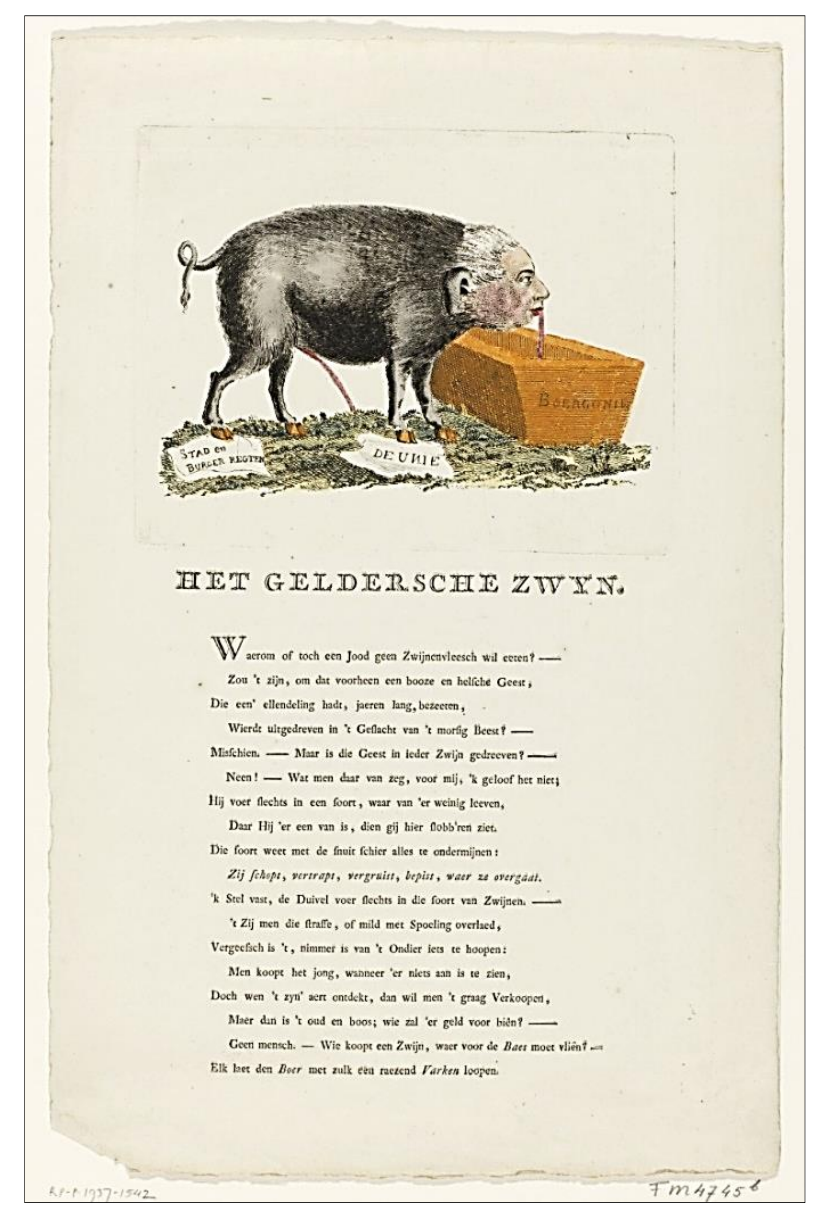

Afbeelding 3. Spotprent op Willem V, Het Geldersche Zwyn, anoniem, 1786. Rijksmuseum, Amsterdam (catalogusnr.: FMH 4745-b)

Een van de spotprenten die de persoon van de laatste stadhouder in een kwaad daglicht zette, was de prent getiteld "Het Geldersche Zwyn", anoniem gepubliceerd in $1786 .{ }^{12}$ Willem V krijgt op de prent een afstotend varkenslijf: hij laat zijn urine lopen op "De Unie" van Utrecht en vertrapt "Stad en Burger regten". Daarbij braakt hij in een trog gevuld met Bourgondische wijn, zoals het opschrift op de trog ("Boergonie") zou suggereren. De versregels die onder de prent zijn geplaatst voltooien het hele werk. De titel van

${ }^{12}$ De auteur van deze prent was vermoedelijk Jan Verlem, de Amsterdamse drukker bij wie o.a. De Politieke Kruyer werd uitgegeven. 
de spotprent is een duidelijke toespeling op het optreden van de prinselijke troepen in twee Gelderse stadjes, Hattem en Elburg, dat in het najaar van 1786 plaatsvond. De strijd tussen de orangisten en de patriotten die tot dan toe tot "geweld op papier" beperkt was, verkreeg daarmee een duidelijk militair karakter (Prins 149). De interventie van het prinselijke leger in beide steden was gericht tegen het republikeinse bestel: tot halverwege de achttiende eeuw mochten de raadsleden en ambtsdragers door de burgers zelf gekozen worden (Schama 143-144). Willem V wilde daar een einde aan maken.

De val van Hattem en Elburg bracht een schok in de Republiek teweeg, wat zelfs tot in de Amsterdamse schouwburg resoneerde (Haas 53). ${ }^{13}$ Sindsdien werd Willem $\mathrm{V}$ als een wellustige tiran gepresenteerd en de polemiek rond zijn persoon werd nogal verscherpt. Dat zien we juist op het voorbeeld van de prent "Het Geldersche Zwyn" - "een van de gemeenste en doeltreffendste spotprenten op de prins" (Grijzenhout 219). De symboliek van de afbeelding en de retoriek van de bijbehorende tekst hebben een duidelijke antimonarchistische (en daarmee republikeinse) strekking. De fundamenten van het republikeinse bestel van Nederland - de Unie van Utrecht en de lokale burgerrechten - werden door de stadhouder geminacht, wat zijn absolutistische imago alleen maar versterkte. In de tekst onder de prent werd aan dat vijandbeeld extra kracht bijgezet. Een algemene afkeer tegen het zwijn - een dier dat door de duivel bezeten lijkt te zijn - werd snel in menselijke angst veranderd. Deze overgang markeerde ook een duidelijke verandering van het imago van Willem $\mathrm{V}$ in de loop van de achttiende eeuw: lof en vreugde bij de geboorte van de prins werden snel veranderd in haat en minachting van de republikeinse burgers jegens hem. In de tekst wordt dat als volgt geformuleerd:

Men koopt het [zwijn - JU] jong, wanneer 'er niet aan is te zien,

Doch wen 't zyn' aert ontdekt, dan wil men 't graag Verkoopen,

Maer dan is 't oud en boos; wie zal 'er geld voor biên? -

Geen mensch. - Wie koopt een Zwijn, waer voor de Baes moet vlien?

De "baes" - het Nederlandse volk (of tenminste het republikeinsgezinde deel daarvan) moest aan dat "vlien" een einde maken. Daarvoor juist werd

${ }^{13}$ Des te meer is het verwonderlijk dat deze historische gebeurtenis in de Nederlandse geschiedenis weinig is besproken. Tim Prins merkt in zijn artikel "De val van Hattem en Elburg (1786) in de patriotse en de prinsgezinde pers" terecht op dat de vrijwel enige analyse van de inname van de Gelderse steden door de Oranjes het boek van Hendrik Abraham Weststrate uit 1903 biedt (Gelderland in den patriottentijd, 1903). 
een radicale polemiek op gang gebracht die ten doel had Willem $\mathrm{V}$ en zijn entourage in een kwaad daglicht te stellen.

De besproken spotprent was slechts een van talrijke voorbeelden van de radicalisering van de politieke polemiek gericht tegen de semi-absolutistische macht van de orangisten. Andere, meestal anonieme, auteurs gingen nog verder om Willem $\mathrm{V}$ en zijn hof zwart te maken, of zelfs uit het politieke toneel te weren. Een anonieme auteur van het pamflet getiteld Opwekking aen de burgery van Nederland (1782) - een tekst die qua algemene strekking gelijkenissen met de strijdkreet van Van der Capellen van een jaar eerder vertoonde - eiste zelfs de dood van de stadhouder, waarbij "een nieuwe Brutus" een handje moest helpen (Leemans \& Johannes 690). Dat leek de enige oplossing, anders zou het Nederlandse volk onder de brute onderdrukking door de Oranjes blijven lijden en zijn eigen leven riskeren. Willem V werd namelijk in deze kritische, venijnige optiek als een wrede tiran voorgesteld, gericht op eigenbelang, wraakzucht en geldgewin. In de patriottische pers werd hij vaak als "Willem den Bloeddorstigen" aangeduid (Hollandsche Historische Courant, 1786). Andere auteurs spraken in dezelfde context over een "Gevloekte Landsverraar" en "aartsgeweldenaar". ${ }^{14}$

Dit imago van Willem V als antiheld werd ook op het toneel voortgezet. De eerder genoemde Simon Stijl koos echter een andere voorstelling voor de prins. In zijn satirische toneelstuk De torenbouw van het vlek Brikkekiks in het landschap Batrachia (1788) komt Willem V voor als een slappeling die een zwak heeft voor zijn despotische vrouw. Van het beeld van de brute geweldenaar die de dood verdient blijft bij Stijl niet zo veel over. ${ }^{15}$ In plaats van een waarschuwing voor de despotische tiran, vinden we hier passages die Willem V in eerste instantie belachelijk moesten maken.

De stroom van anti-orangistische propaganda moest natuurlijkerwijs een reactie uitlokken bij de aanhang van de Oranjes. Die reacties waren echter minder geslaagd en de impact ervan veel zwakker dan bij de opponenten, een duidelijk teken dat de orangistische schrijvers voorlopig in het defensief zaten (Leemans \& Johannes 693). In de pro-orangistische teksten wordt het beeld van Willem $\mathrm{V}$ als een zwakke sul in een imago van een rustige en

\footnotetext{
${ }^{14}$ Zie daarvoor: Batoos kroost aan Willem de Vyfde, Prins van Oranje, verrooveraar van de twee onbevolkte stedekens Hattum en Elburg, protector van de burger-bezoldelingen, welke hy als capitein generaal herschept heeft in burger-moorders! (Amsterdam 1786); Aan Nymeegsch volk, by de naderende komst van Willem den Vijfden (z.p. 1786).

${ }_{15}$ Andere toneelstukken waarin het negatieve imago van Willem V werd voortgezet, zijn bijv. De Eigenbaat van Bernardus Bosch (1784) of een anoniem verschenen stuk David en Batseba (ca. 1799).
} 
zachtmoedige heerser omgezet; in plaats van een bloeddorstige tiran vinden we hier een vorst die de beste garantie is voor het behouden van burgerrechten en rust in het land. ${ }^{16}$

\section{SAMENVATTING EN CONCLUSIES}

In het achttiende-eeuwse Europa voerden monarchieën als Frankrijk, Engeland en Pruisen de boventoon. Nederland, samen met de Italiaanse stadstaten en het Zwitserse Eedgenootschap, vormden hierop een uitzondering. Om deze uitzonderlijke positie te handhaven moest men stelselmatig handelen. Schrijvers, journalisten en politieke denkers hebben een systeem in het leven geroepen, waarbij door middel van teksten en prenten de voordelen van het republicanisme uiteengezet en de gevaren van het monarchisme uitvergroot werden. Dit bracht een heftige discussie tot stand die een belangrijk element was van de patriottenrevolutie.

De strategie van de patriottische aanhang om de republikeinse idealen te verspreiden was simpel. Men beriep zich op klassieke voorbeelden van Sparta of de Romeinse Republiek die tegengesteld waren aan de tirannie van het monarchale staatsbestel. Een dergelijke tegenstelling projecteerde men verder op de eigentijdse realiteit. De klassieke helden zoals Cicero, Cato of Lucius Junius Brutus werden de Nederlandse lezer als voorbeeld van de virtus voorgehouden - een burgerlijke deugd bij uitstek die, zo nodig, de hoogste opoffering verdiende. Het meest treffende voorbeeld van dergelijke deugd vonden de Nederlanders in de eigen vaderlandse geschiedenis terug: in het beeld van Claudius Civilis lagen de virtus, liefde voor eigen volk en de vrijheidszin opgesloten. Zo ontstond de Bataafse mythe - een belangrijk component van de vorming van het Nederlandse identiteitsbesef, waarbij de republikeinse gedachten een cruciale rol speelden. De overtuiging dat de Nederlanders (Bataven) sinds de tijd van Claudius Civilis voorzien waren van republikeinse vrijheidsgenen werd in de mythe duidelijk geformuleerd. Dat veroorzaakte de onbegrensde liefde voor vrijheid bij de Nederlanders die doof leken te zijn voor de waarschuwende stemmen die de gebreken van het republikeinse stelsel blootlegden.

Deze natuurlijke drang naar vrijheid moest echter constant gehandhaafd blijven. Daarvoor verspreidde men het ideaal van de actieve burger dat

\footnotetext{
${ }^{16}$ Voor het positieve imago van Willem V zie o.a.: Van Goens, 1781-1783 of Le Francq van Berkhey, 1782.
} 
noodzakelijk was om evenwicht in de staat te houden: vooral in de situatie waarin de Nederlandse Republiek aan het einde van de achttiende eeuw steeds vaker haar monarchale gelaat toonde. De pamfletten, zoals Aan het volk van Nederland, benadrukten de burgerlijke noodzaak om de macht in eigen handen te nemen en de voorkiemen van het orangistische absolutisme in de kiem te smoren. Aan het volk van Nederland verkreeg een klassieke context - het voorbeeld van de strijdlustige burgers die de macht overnemen, vond de auteur van het pamflet, Van der Capellen, in het klassieke Sparta, maar ook in het zeventiende-eeuwse Engeland terug. De klassieke entourage rond de patriottische auteur was zelfs na zijn dood aanwezig - zijn stijl werd met die van Lucius Junius Brutus vergeleken en het ontwerp van zijn sculptuur deed aan een Romeinse volkstribuun denken.

De politieke betrokkenheid van de patriottisch ingestelde Nederlanders nam vaak de vorm aan van heftige kritiek op hun tegenstanders. Deze kritiek was zowel in de pers als op het toneel te vinden. Ze maakte gebruik van simpele middelen en associaties. Zo had Willem V, de vertegenwoordiger van de monarchistische staat, heel wat te verduren: het beschimpen van zijn persoon, het uitvergroten van zijn misdaden en het zwartmaken van zijn hoffelijke entourage leidden langzamerhand tot de marginalisering van zijn invloed op de landelijke politiek. Zo is Willem V een van de eerste slachtoffers van het mediaoffensief geworden en de pennenstrijd, waarbij de republikeinse idealen een belangrijke rol speelden, leek tijdelijk door de patriottische aanhang gewonnen.

\section{BIBLIOGRAFIE}

Aan Nymeegsch volk, by de naderende komst van Willem den Vijfden. z.p., 1786.

Allart, Johannes. De Vryheid. Amsterdam, Johannes Allart, 1783.

[Batavus = Bernardus Bosch]. Batoos kroost aan Willem de Vyfde, Prins van Oranje, verrooveraar van de twee onbevolkte stedekens Hattum en Elburg, protector van de burgerbezoldelingen, welke hy als capitein generaal herschept heeft in burger-moorders! Amsterdam, Jan Verlem, 1786.

Beaufort, Levinus Ferdinand de. Verhandeling van de vryheit in den burgerstaet. Leiden/ Middelburg, S. Luchtmans/L. Bakker, 1737.

Bedaux, Jan Baptist, Agnes Groot, en Aernout Hagen "Allegorieën van goed bestuur; het decoratieprogramma van het stadhuis van Enkhuizen (1687-1710)". Jaarboek Monumentenzorg, 1992, pp. 142-180.

Berg, Arie van der. De papieren oorlog tussen patriotten en prinsgezinden: 'het geldersche zwyn'. Nijmeegs Museum Commanderie van Sint-Jan, 1987. 
Berkhey, Joannes le Francq van. De zeetriumph der Bataafsche vrijheid. Amsterdam, J. Allart, 1782.

Capellen tot den Pol, Joan van der. Aan het volk van Nederland, ed. Willem Frederik Wertheim en Annie Hetty Wertheim-Gijse Weenink, Weesp, Heureka, 1981.

Dam, Willem van Irhoven van. Vyfde missive van Candidus aan den schryver van het politiek vertoog, dienende ter wederlegging van hetzelve. Rotterdam, z.n., 1782.

De Ouderwetse Nederlandsche Patriot. Den Haag, P.F. Gosse, 1781-1783.

De Politieke Kruyer. Amsterdam, Verlem, 1782-1787.

De Post van den Neder-Rhyn. Utrecht, G.T. van Paddenburg, 1781-1787.

Eikema Hommes, Margriet van, en Piet Bakker. "Hoogachtbaarheid en ontzaglijke grootheid. De burgemeesterskamer van het stadhuis van Enkhuizen". Romeyn de Hooghe. De verbeelding van de late Gouden Eeuw, ed. Henk van Nierop. Zwolle, Wbooks, 2008, pp. 222-243.

Evers, M. 'Angelsaksische inspiratiebronnen voor de patriottische denkbeelden van Joan Derk van der Capellen.' 1787 De Nederlandse revolutie?, ed. Theo S.M. van der Zee, Amsterdam, De Bataafsche Leeuw, 1988, pp. 206-217.

Gelderen, Maarten van. "De Nederlandse Opstand (1555-1610): van 'vrijheden" naar 'oude vrijheid' en de 'vrijheid der conscientien'". Vrijheid. Een geschiedenis van de vijftiende tot de twintigste eeuw, ed. E.O.G. Haitsma Mulier en W.R.E. Velema, Amsterdam University Press, 1999, pp. 27-52.

Grijzenhout, Frans. "Sneeuwballen tegen de macht. Politiek en satire omstreeks 1800". Het Bataafse experiment. Politiek en cultuur rond 1800, ed. Frans Grijzenhout, Wieger Velema en Niek van Sas, Nijmegen, Vantilt, 2013, pp. 27-64.

Haas, Anna de. "Een onbekende traditie in de Amsterdamse schouwburg. De tussenspelen in Focquenbrochs Min in 't lazarushuis (ca. 1760-1818)". Jaarboek Amstelodamum, vol. 103, 2011, pp. 36-69.

Haitsma Mulier, Eco. "De Bataafse mythe opnieuw bekeken”. BMGN, vol. 111, 1996, pp. 344-367.

Haverkorn, Willem (de jonge). Claudius Civilis; treurspel. I. Duim, 1779. Hollandsche historische courant. 1733-1788. Delft, Reinier Boitet.

Het Geldersche Zwyn (spotprent op Willem V). Amsterdam, Jan Verlem, 1786.

Klein, Stephan. Patriots republikanisme. Politieke cultuur in Nederland 1766-1787. Amsterdam University Press, 1995.

Kossmann, Maarten. Politieke theorie en geschiedenis. Amsterdam, Bert Bakker, 1987.

Le Politique Hollandais. Amsterdam, J.A. Crajenschot (e.a.), 1781-1784.

Leemans, Inger, en Gert-Jan Johannes. Worm en donder. Geschiedenis van de Nederlandse literatuur 1700-1800: de Republiek. Amsterdam, Bert Bakker, 2013.

Maddox, Graham. 'Constitution.' Political Innovation and Conceptual Change, ed. Terence Ball, James Farr, en Russel L. Hanson, Cambridge University Press, 1989, pp. 50-67.

Meerkerk, Edwin van. Willem V en Wilhelmina van Pruisen: de laatste stadhouders. Atlas, 2009.

Meijer, Fik. Keizers sterven niet in bed. Van Caesar (44 v. Chr.) tot Romulus Augustus (476 n. Chr.). Amsterdam, Athenaeum-Polak \& Van Gennep, 2001.

Montagu, Edward Wortley. Reflections on the Rise and Fall of the Ancient Republics, Adapted to the Present State of Great Britain, 2e uitgave, London, A. Millar, 1760.

Mörke, Olaf. "De politieke cultuur van Duitsland en de Republiek. Dezelfde wortels, een andere uitkomst". Een wonder weerspiegeld. De Nederlandse Republiek in Europees perspectief, ed. Karel Davids en Jan Lucassen, Amsterdam, Aksant, 2005. 
Nassau la Leck, Lodewijk Theodoor van. Politieke brieven over verscheide gewichtige onderwerpen, betreklyk, zo tot het staatkundig als huishoudelyk bestier der Republiek. Utrecht, G.T. van Paddenburg, 1780.

Prins, Tim. "De val van Hattem en Elburg (1786) in de patriotse en de prinsgezinde pers". Mededelingen van de Stichting Jacob Campo Weyerman, vol. 35, 2012, pp. 149-160.

Robertson, John. The Scottish Enlightenment and the Militia Issue. Edinburgh, J. Donald, 1985.

Rosendaal, Joost. Bataven! Nederlandse vluchtelingen in Frankrijk 1787-1795. Nijmegen, Vantilt, 2003.

Sas, Niek van. De metamorfose van Nederland. Van oude orde naar moderniteit 1750-1900. Amsterdam University Press, 2004.

Schama, Simon. Patriotten en bevrijders. Revolutie in de Noordelijke Nederlanden, 1780-1813. Amsterdam, Agon, 1989.

Stijl, Simon. De torenbouw van het vlek Brikkekiks in het landschap Batrachia, ed. A.N.M. Wijngaards en N.C.H. Wijngaards, Zutphen, Thieme, 1975.

Stijl, Simon. Opkomst en bloei der verenigde Nederlanden. Amsterdam, P. Conradie/Harlingen, F. van der Plaats \& Junior, 1774.

Velema, Wyger. "Republikeinse democratie. De politieke wereld van de Bataafse Revolutie, 1795-1798". Het Bataafse experiment. Politiek en cultuur rond 1800, ed. Frans Grijzenhout, N.C.F. van Sas, Wyger Velema, Nijmegen, Vantilt, 2013, pp. 27-64.

Velema, Wyger. Omstreden Oudheid. De Nederlandse achttiende eeuw en de klassieke politiek. Amsterdam University Press, 2010.

Wessels, L.H.M. "Over invloed en traditie. Een plaatsbepaling van Joan Derk van der Capellen". De wekker van de Nederlandse natie. Joan Derk van der Capellen 1741-1784, ed. E.A. van Dijk, J. Trijsburg, W.F. Wertheim, en A.H. Wertheim-Gijse Weenink, Zwolle, Waanders, 1984, pp. 125-135.

Wildschut, Arie. Goejanverwellesluis: de strijd tussen patriotten en prinsgezinden, 1780-1787. Hilversum, Verloren, 2000.

Zillesen, Cornelis. Onderzoek der oorzaaken van de opkomst, het verval en herstel, der voornaamste oude en hedendaagsche volken. Utrecht, G. van den Brink, Jansz. 1781-1784.

Zillesen, Cornelis. Welmeenende raad aan myn vaderland. Dordrecht, A. Blussé en zoon, 1785.

Zwitser, H.L. Joan Derk van der Capellen. Aan het volk van Nederland. Het patriottisch program uit 1781. Amsterdam, De Bataafsche Leeuw, 1987.

\section{WOLNOŚĆ, ZAANGAŻOWANIE OBYWATELSKIE I KRYTYKA ABSOLUTYZMU: \\ KILKA PRZYKŁADÓW NIDERLANDZKIEGO REPUBLIKANIZMU W OŚWIECENIU}

Streszczenie

W niniejszym artykule przedstawiam rozwój myśli republikańskiej w Niderlandach w ostatnich dziesięcioleciach osiemnastego wieku. W tym celu prezentuję trzy przykłady postaw republikańskich, które moim zdaniem wywarły największe piętno na tworzenie się niderlandzkiej tożsamości narodowej w czasach przedwspółczesnych. Analiza przykładów ma za zadanie oddać sposób, w jaki powstawało republikańskie myślenie w umysłach Niderlandczyków. W tym celu 
badam zarówno ideologię republikańskich ideałów, jak i ich warstwę retoryczną - to, w jaki sposób przekazywane były w formie tekstów i obrazów ówczesnemu odbiorcy.

Słowa kluczowe: republikanizm; wolność; Oświecenie; Wilhelm V; starożytność; mit batawski; satyra polityczna; krytyka, patrioci.

\section{FREEDOM, CIVIL ACTIVISM AND CRITICS OF THE ABSOLUTISM: SOME CASES OF THE DUTCH REPUBLICANISM IN ENLIGHTENMENT}

\section{S u m m a r y}

The purpose of this contribution is to show how republican thought in the Netherlands developed during the last decades of the eighteenth century. To this end, I present three cases of Dutch republicanism, which, I believe, were the most crucial in the formation of Dutch identity in the early modern period. When analysing these cases, I try to show how the republican message came about: I look both at the ideology that was embedded in republican concepts, and at the rhetorical representation of republican ideas - how, in the form of texts and prints, they were presented to the reader.

Key words: republicanism; freedom; Enlightenment; William V; antiquity; the Batavian myth; political satire; criticism; patriots. 